\title{
ANALISIS KUALITAS DAN UJI ORGANOLEPTIK MINUMAN BUAH NANAS QUEEN (ANANAS COMOSUS (L) MERR.)
}

\section{Quality Analysis and Organoleptic Assessment of Pineapple Queen (Ananas comosus (L) Merr.) Fruit Drink}

\author{
Yustita Nuraeni ${ }^{1 *}$, Susinggih Wijana ${ }^{1}$, Bambang Susilo ${ }^{2}$ \\ ${ }^{1}$ Jurusan Teknologi Industri Pertanian - Fakultas Teknologi Pertanian - Universitas Brawijaya \\ ${ }^{2} J u r u s a n$ Teknik Mesin Pertanian - Fakultas Teknologi Pertanian - Universitas Brawijaya \\ Jl. Veteran - Malang 65145 \\ *Penulis Korespondensi: email: yustitanuraeni@yahoo.com
}

Disubmit: 5 Januari 2018 Direvisi: 30 November 2018 Diterima: 01 Maret 2019

\begin{abstract}
ABSTRAK
Indonesia merupakan salah satu penghasil nanas di dunia, dan pada tahun 2013 produksinya menempati urutan ke-5 dunia. Sentra produksi nanas Jawa Timur berada di Kabupaten Kediri dan Kabupaten Blitar, dan varietas yang umum ditanam adalah Queen, namun $10-15 \%$ panen berupa nanas grade $C$ yang memiliki ukuran terkecil, dibandingkan grade lainnya. Pada penelitian ini nanas Queen grade $C$ diolah menjadi minuman buah, dibandingkan kualitasnya dengan produk sejenis yang diolah dari nanas Queen grade B menggunakan analisis komparatif $t$-test independent, dan dibandingkan pula dengan regulasi dari BPOM. Uji sifat organoleptik minuman buah nanas Queen grade C menggunakan acceptance test just-about-right-scale (JARS) yang dikombinasikan dengan overall acceptibilty. Hasil analisa t-test independent menunjukkan bahwa seluruh nilai thitung pada rentang nilai (-) 4.604 sampai dengan (+) 4.604 sehingga H0 diterima, yang berarti tidak ada perbedaan nilai rata-rata kualitas antara minuman buah nanas Queen grade C dengan minuman buah nanas Queen grade B. Persentase sari buah pada minuman buah nanas Queen grade $C$ telah memenuhi kategori sebagai minuman buah BPOM. Hasil uji organopleptik menunjukkan bahwa atribut sensori pada minuman buah nanas Queen dinilai telah tepat dan tidak memerlukan perubahan komposisi bahan baku dan bahan tambahan
\end{abstract}

Kata kunci: Just-About-Right-Scale (JARS); Nanas Queen; Overall Acceptibilty; t-test Independent

\begin{abstract}
Indonesia is one of the pineapple producers, ranked fifth in the world. Kediri and Blitar are the centres of pineapple production in east Java regencies, and the most variety planted is queens. However 10$15 \%$ of the plants are pineapple class $C$, which is categorised as the smallest size of pineapple in Indonesia. In this study, the Queen C grade pineapple was processed into fruit drinks, compared with its quality with similar products processed from Queen B using comparative analysis $t$-test independent, and also compared with regulation from BPOM. Organoleptic test of pineapple Queen grade C drink using A acceptance test just-about-right-scale (JARS) combined with overall acceptibilty. The result of $t$-test independent analysis showed that all tc values between (-) 4.604 to (+) 4.604 thus $\mathrm{HO}$ are accepted, which means that there is no difference quality mean value between pineapple Queen grade $C$ drink and grade $B$ drink. The percentage of fruit juice in pineapple Queen grade C drink has been categorized as BPOM fruit drink. The organopleptic test results showed that the sensory attributes of pineapple Queen grade C drink were considered appropriate and does not require changes in the composition of raw material and other ingredients
\end{abstract}

Keyword: Just-about-right-scale (JARS); Pineapple Queen; Overall acceptibilty; t-test independent 


\section{PENDAHULUAN}

Buah nanas (Ananas comosus (L) Merr.) menempati urutan ketiga sesudah pisang dan jeruk sebagai buah terpenting produksinya di dunia (Siddiq, 2012). Data Food and Agriculture Organization of The United Nations (2013) menunjukkan bahwa pada tahun 2013 produksi nanas di Indonesia menempati urutan ke-5 dunia dengan nilai sebesar 1.78 juta ton.

Tanaman nanas dapat tumbuh dengan baik di Indonesia (Samadi, 2014). Data Badan Pusat Statistik (BPS) (2015) menunjukkan bahwa produksi nanas di Indonesia pada tahun 2015 adalah 1.73 juta ton dan Jawa Timur menempati urutan ke-5 dengan produksi sebesar 171 ribu ton.

Sentra nanas di Jawa Timur berada di daerah sekitar Gunung Kelud yang terbagi ke dalam wilayah Kabupaten Kediri dan Kabupaten Blitar. Berdasarkan Badan Pusat Statistik Kabupaten Kediri (2016) dan Badan Pusat Statistik Kabupaten Blitar (2016), produksi nanas di Kabupaten Kediri sebesar 115 ribu ton atau $67.17 \%$ dan disusul oleh Kabupaten Blitar sebesar 16 ribu ton atau 9.60\% dari panen di Jawa Timur.

Nanas yang dihasilkan dari Kabupaten Kediri dan Blitar umumnya adalah varietas Queen, namun sebagian produksinya merupakan subgrade yang tidak memenuhi standar ukuran permintaan pasar dan tergolong sebagai nanas Queen grade C. Penelitian Tiara (2014) memperkirakan bahwa untuk setiap panen nanas Queen di daerah Blitar terdapat subgrade sebanyak $10 \%$, dan nanas ini akan dibuang, tidak dipanen, atau digunakan sebagai bibit. Pihak Penyuluh Pertanian Kabupaten Kediri yang bertugas di Gunung Kelud menyampaikan bahwa produksi nanas subgrade sebesar 10-15\% dari setiap panen.

Standar mutu nanas Queen terbagi menjadi 4 kelas yaitu grade Super, grade A, grade $B$ dan grade $C$. Setiap grade memiliki kadar gula yang sama yaitu 11-15 obrix, dan warna kulit buah yang sama yaitu agak kuning. Faktor yang membedakannya hanya ukuran buahnya saja, yaitu grade B memiliki panjang 10.00-13.90 cm dan bobot 0.40-0.69 $\mathrm{kg}$, sedangkan grade $\mathrm{C}$ memiliki panjang $\leq$ $9.90 \mathrm{~cm}$ dan bobot $\leq 0.40 \mathrm{~kg}$ (Direktorat Budidaya Tanaman Buah, 2010). Hal ini sesuai dengan informasi dari pihak Penyuluh Pertanian Kabupaten Kediri yang bertugas di
Gunung Kelud, bahwa nanas Queen grade C merupakan buah yang sudah matang namun ukurannya lebih kecil.

Buah nanas dapat diolah menjadi minuman sari buah (Samadi, 2014). Nanas Queen merupakan salah satu varietas utama untuk produksi sari buah (Featherstone, 2016). Buah nanas yang berukuran kecil dapat dimanfaatkan sebagai bahan bakunya (Featherstone, 2016; Sinha et al., 2012).

Minuman buah merupakan minuman yang terdiri dari satu atau lebih jenis buah dengan total sari buah 10-35\% (b/v) (Badan Pengawasan Obat dan Makanan, 2016). Mengacu Khairani dan Dalapati (2007), pada saat pembuatan minuman buah nanas terdapat penambahan volume air pengencer sebanyak dua kali berat bubur buah dan penyaringan menggunakan kain saring. Bahan tambahan berupa natrium benzoat $0.5 \mathrm{~g} / \mathrm{l}$, gula pasir $130 \mathrm{~g} / \mathrm{l}$, asam sitrat $1 \mathrm{~g} / \mathrm{l}$, dan carboxymethyl cellulose (CMC) $2 \mathrm{~g} / 1$. Dilanjutkan dengan pemanasan pada suhu $85^{\circ} \mathrm{C}$ selama 10 menit, pengemasan ke dalam botol steril, proses exhausting, penutupan botol, dan dimasukkan ke dalam air mendidih selama 15 menit. Diikuti dengan pendinginan dan penyimpanan, sedangkan pada Yusmarini, et al. (2015), menggunakan perbandingan buah:air sebesar 1:1 (b:v), dan bahan tambahan berupa gula $150 \mathrm{~g} / \mathrm{l}$, asam sitrat $2 \mathrm{~g} / \mathrm{l}$ dan CMC $0.5 \mathrm{~g} / 1$. Namun pada Khairani dan Dalapati (2007) dan Yusmarini et al. (2015) tersebut tidak terdapat penjelasan mengenai jenis nanas yang digunakan.

Acceptance testing adalah prosedur untuk mengukur tingkat kesukaan atau ketidaksukaan konsumen terhadap makanan. Acceptance scaling bisa dilakukan pada satu produk saja, dan just-about-right scales (JARS) merupakan skala yang didesain untuk mengukur reaksi panelis terhadap atribut tertentu (Lawless and Heymann, 2010). Skala JARS dapat dikombinasikan dengan overall acceptibilty, dan dianalisa menggunakan penalty (mean drop) yang merupakan metode analisa untuk menentukan apakah penilaian JARS terhadap sifat tertentu terkait dengan penurunan pada overall liking (Rothman and Parker, 2009)

Oleh karena itu, penelitian ini dilakukan untuk mengetahui kualitas minuman buah hasil olahan dari buah nanas Queen grade $C$ dan membandingkannya dengan produk sejenis yang diolah dari nanas Queen grade B. Dilanjutkan dengan uji organoleptik 
untuk mengetahui tingkat ketepatan atribut rasa dan tingkat kesukaan konsumen terhadap minuman buah.

\section{METODE}

Bahan baku yang digunakan yaitu nanas Queen grade C dan grade B (Ananas comosus L. Merr) yang telah matang pohon dengan tanda sebanyak 60-80\% kulit buah telah menguning. Nanas Queen grade C yang digunakan berbobot 246-373 g dan panjang 7.40-9.50 cm. Nanas Queen grade B yang digunakan berbobot 628-686 g dan panjang 13.00 - $13.50 \mathrm{~cm}$. Penghitungan bobot dan panjang buah tersebut pada kondisi tanpa mahkota buah.

Semua bahan diperoleh langsung dari daerah Gunung Kelud kecamatan Ngancar, kabupaten Kediri. Bahan tambahan yaitu: gula pasir, asam sitrat dan CMC yang diperoleh dari toko Primarasa-Malang, natrium benzoat yang diperoleh dari toko Makmur Sejati-Malang.

Bahan untuk analisa kualitas kimia yaitu aquades, NAOH $0.1 \mathrm{~N}$, indikator PP, larutan glukosa standar $0.2 \mathrm{mg} / \mathrm{ml}$, dan pereaksi anthrone, alkohol 96\%, dan media PCA (Plate Count Agar-OXOID)

Peralatan untuk pembuatan minuman buah nanas yaitu pisau stainless steel, wadah plastic, juicer merk Electrolux EJE 3000, pengepres hidrolik, kain saring \pm 75 mesh, panci porcelain enamel on steel, pocket refractometer PAL-3 Atago, timbangan digital, termometer, gelas ukur pyrex, kompor gas dan pengaduk.

Peralatan untuk analisa karakteristik produk adalah forced draft oven, pipet tetes, tabung reaksi, glass beaker, desikator, colorimeter, pocket refractometer PAL-3 Atago, elcometer 2300RV, corong kecil, waterbatch (Memmert), spectrofotometer (Shimadzu), kuvet, cawan petri, mikropipet, timbangan analitik, kompor, kapas, kasa, Bunsen, dan kertas coklat.

\section{Metode Pembuatan Minuman Buah}

Proses produksi minuman buah pada penelitian ini mengacu pada penelitian sebelumnya, yaitu buah nanas yang telah dibuang mahkotanya dicuci menggunakan air yang mengandung sodium hypochlorite ( $\mathrm{NaClO}$ $200 \mathrm{mg} / \mathrm{l})$, ditiriskan, dikupas, dipotong menjadi ukuran $\pm 3 \mathrm{~cm} \times 3 \mathrm{~cm} \times 3 \mathrm{~cm}$, dan dilumatkan menggunakan juicer kecepatan 8000 rpm hingga menghasilkan bubur buah nanas. Selanjutnya, ditambahkan volume air sebanyak dua kali berat bubur buah, dimasukkan kedalam kain saring berukuran \pm 75 mesh dan dipres menggunakan pengepres hidrolik tekanan 100 bar/Psi hingga menghasilkan ampas dan air buah nanas.

Air buah nanas diukur sebanyak 1 liter dan dicampur dengan gula $100 \mathrm{~g} / 1$, asam sitrat $1 \mathrm{~g} / 1$, CMC $0.5 \mathrm{~g} / 1$ dan natrium benzoat $0.5 \mathrm{~g} / 1$. Campuran ini dipanaskan di dalam panci hingga mencapai suhu $85^{\circ} \mathrm{C}$ selama 5 menit, dimasukkan kedalam botol kaca, diexhausting selama 30 menit, ditutup dan dipasteurisasi dengan cara dimasukkan ke dalam panci yang berisi air mendidih selama 15 menit. Sesudahnya, botol minuman didinginkan menjadi suhu $25^{\circ} \mathrm{C}$.

\section{Rancangan Percobaan}

Minuman buah nanas dibuat dari nanas Queen grade C dan grade B, dan masing-masing diulang sebanyak tiga kali sehingga terdapat 6 satuan percobaan.

\section{Pengujian Mutu Minuman Buah Nanas \\ Analisis Kadar Air (Sudarmadji et al., 2010)}

Sebanyak $5 \mathrm{~g}$ sampel dikeringkan dalam oven pada suhu $100-105{ }^{\circ} \mathrm{C}$ selama 3 jam, didinginkan dalam desikator dan ditimbang. Kemudian dipanaskan lagi dalam oven 30 menit, didinginkan dalam desikator dan ditimbang. Perlakuan ini diulangi sampai tercapai berat konstan (selisih penimbangan berturut-turut kurang dari $0.2 \mathrm{mg}$ ). Pengurangan berat merupakan banyaknya air dalam bahan.

\section{Analisa Kadar Total Gula Metode Anthrone (Apriyantono et al., 1989) \\ Menyiapkan pereaksi anthrone $0.1 \%$} dalam asam sulfat pekat, yang dibuat hanya pada waktu hari akan digunakan. Membuat larutan glukosa standar $0.2 \mathrm{mg} / \mathrm{ml}$, dengan cara sebanyak $200 \mathrm{mg}$ glukosa dilarutkan ke dalam $100 \mathrm{ml}$ akuades, dan ambil $10 \mathrm{ml}$ yang diencerkan menjadi $100 \mathrm{ml}(1 \mathrm{ml}=0.2 \mathrm{mg}$ glukosa).

Cara kerjanya yaitu pipet ke dalam tabung reaksi 0.0 (blanko); 0.2; 0.4; 0.6; 0.8; dan $1.0 \mathrm{ml}$ larutan glukosa standar, kemudian tambahkan air sampai total volume masing-masing tabung reaksi $1.0 \mathrm{ml}$. Tahap selanjutnya tambahkan dengan cepat $5 \mathrm{ml}$ 
Jurnal Teknologi Pertanian Vol. 20 No. 1 [April 2019] 67-78

Analisis Kualitas dan Uji Organoleptik Minuman Buah [Nuraeni dkk]

Tabel 1. Hasil analisa $t$-test independent terhadap karakteristik minuman buah nanas queen grade $\mathrm{C}$ dengan grade B

\begin{tabular}{|c|c|c|}
\hline Karakteristik & $\mathbf{t}_{\text {hitung }}$ & Notasi \\
\hline Kadar Air (\%) & 0.27 & a) \\
\hline Total Gula (\%) & -0.25 & a) \\
\hline Total Asam (\%) & 0.45 & a) \\
\hline Total padatan terlarut (TPT) $\left({ }^{\circ}\right.$ Brix $)$ & 0.49 & a) \\
\hline \multicolumn{3}{|l|}{ Warna } \\
\hline $\mathrm{L}$ & -1.04 & a) \\
\hline$a^{*}$ & -0.43 & a) \\
\hline$b^{*}$ & 0.84 & a) \\
\hline Viskositas (cP) & 1.00 & a) \\
\hline Total plate count (TPC) (koloni/ml) & -0.53 & a) \\
\hline
\end{tabular}

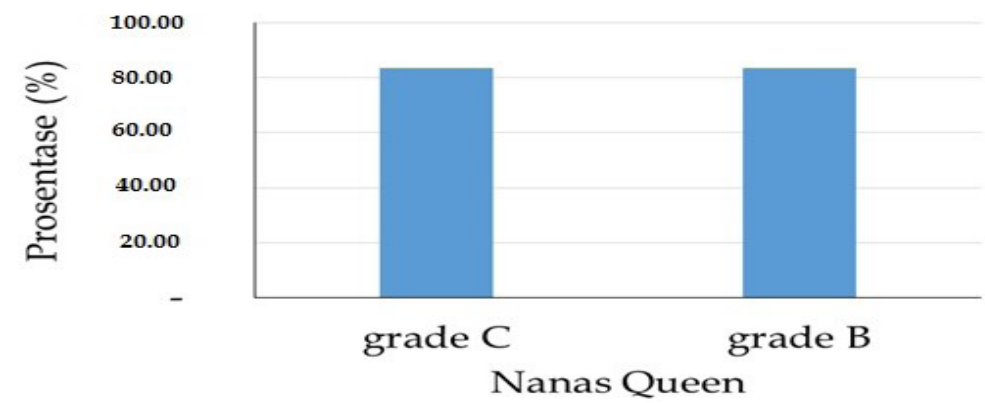

Gambar 1. Rata-rata persentase kadar air terhadap nanas kualitas grade C dan grade B

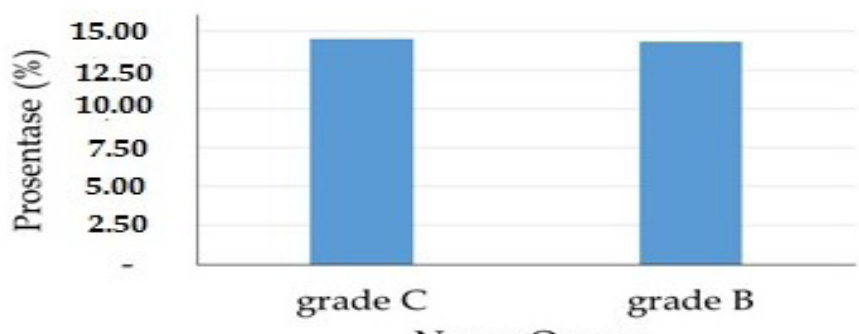

Nanas Queen

Gambar 2. Rata-rata persentase total gula terhadap nanas kualitas grade C dan grade B

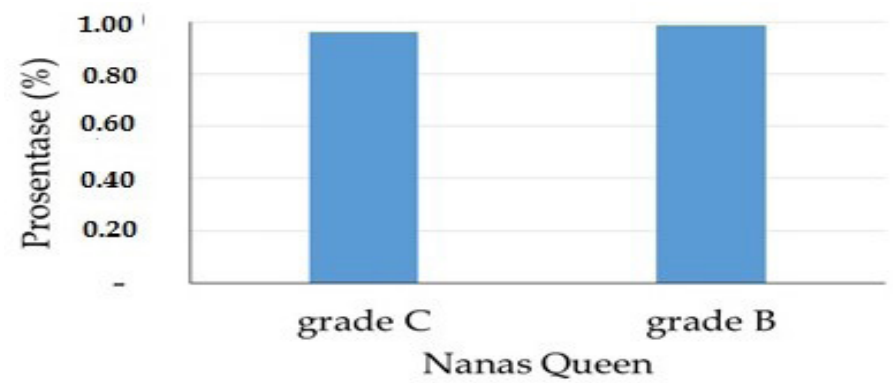

Gambar 3. Rata-rata persentase total asam terhadap nanas kualitas grade $C$ dan grade $B$ 


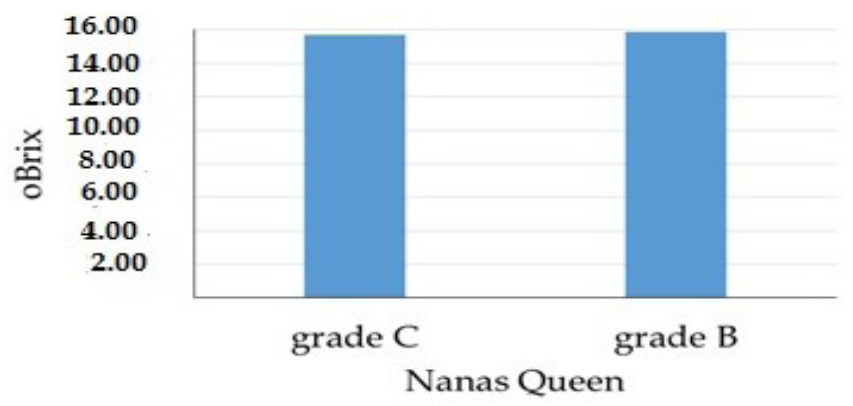

Gambar 4. Rata-rata total padatan terlarut (TPT) terhadap kualitas nanas grade C dan grade B

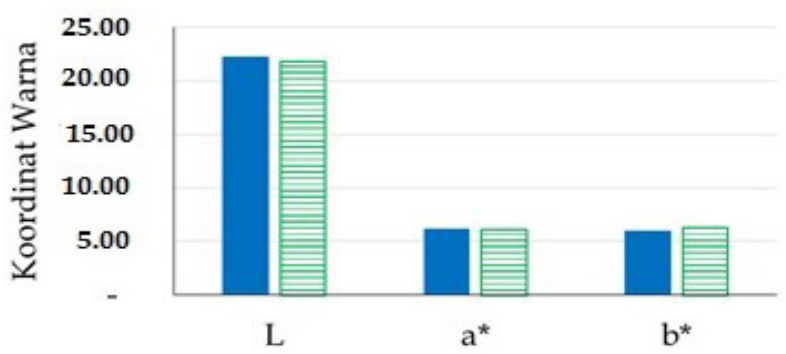

- Nanas Queen grade C $\boxminus$ Nanas Queen grade B

Gambar 5. Rata-rata koordinat warna terhadap kualitas nanas grade C dan grade B

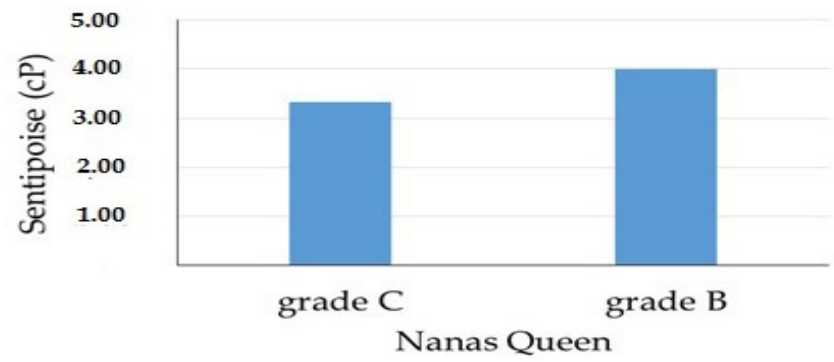

Gambar 6. Rata-rata viskositas terhadap kualitas nanas grade C dan grade B

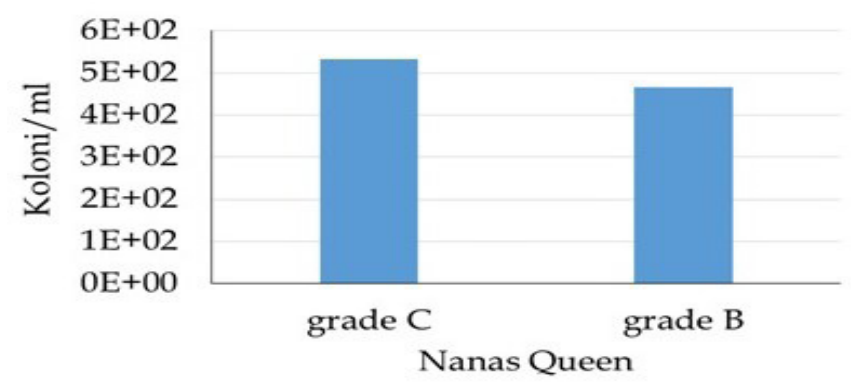

Gambar 7. Rata-rata total plate count (TPC) terhadap kualitas nanas grade C dan grade B 
pereaksi anthrone ke dalam masing-masing tabung reaksi. Tutup tabung reaksi dan campur merata. Tempatkan dalam waterbath 100 ${ }^{\circ} \mathrm{C}$ selama 12 menit. Dinginkan dengan cepat menggunakan air mengalir. Pindahkan ke dalam kuvet, baca absorbansnya pada 630 $\mathrm{nm}$, dan buat kurva hubungan antara absorbans dengan mg glukosa.

Penetapan sampel dengan cara masukkan $1 \mathrm{ml}$ sampel ke dalam tabung reaksi. Selanjutnya lakukan tahap seperti pada pembuatan kurva standar, dan tentukan konsentrasi total gula dalam sampel.

\section{Analisis Total Asam Metode AOAC (Amador, 2011)}

Timbang $5 \mathrm{~g}$ sampel dan dimasukkan ke dalam glass flasks atau glass beaker $250 \mathrm{ml}$, kemudian tambahkan air suling hingga mencapai tanda batas $250 \mathrm{ml}$. Tambahkan $0.75 \mathrm{ml}$ phenolphthalein $(0.3 \mathrm{ml}$ untuk setiap $100 \mathrm{ml}$ larutan), dan campur secara merata. Titrasi dengan larutan $0.1 \mathrm{~N} \mathrm{NaOH}$ hingga menunjukkan warna merah muda yang dapat bertahan selama 30 detik.

Total asam tertitrasi dinyatakan sebagai asam sitrat anhidrat berbasiskan berat,

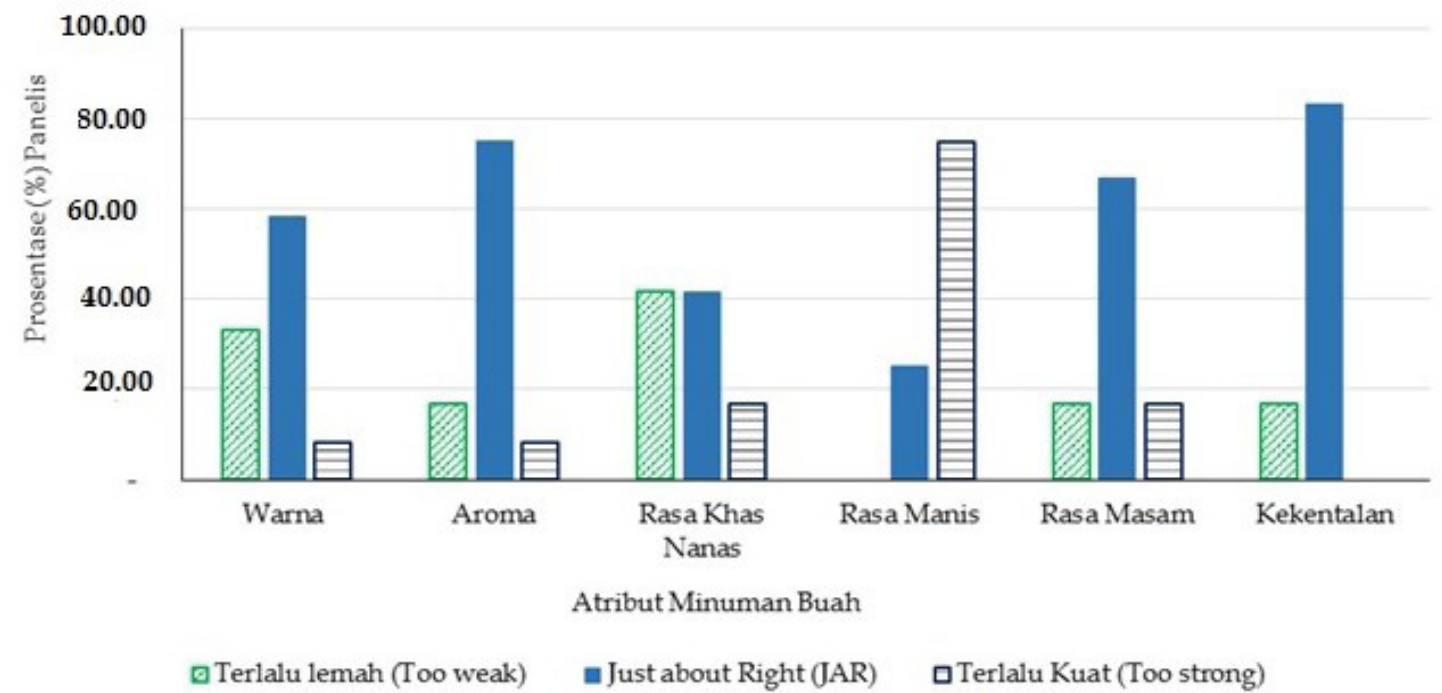

Gambar 8. Respon panelis terhadap tingkat ketepatan atribut minuman buah

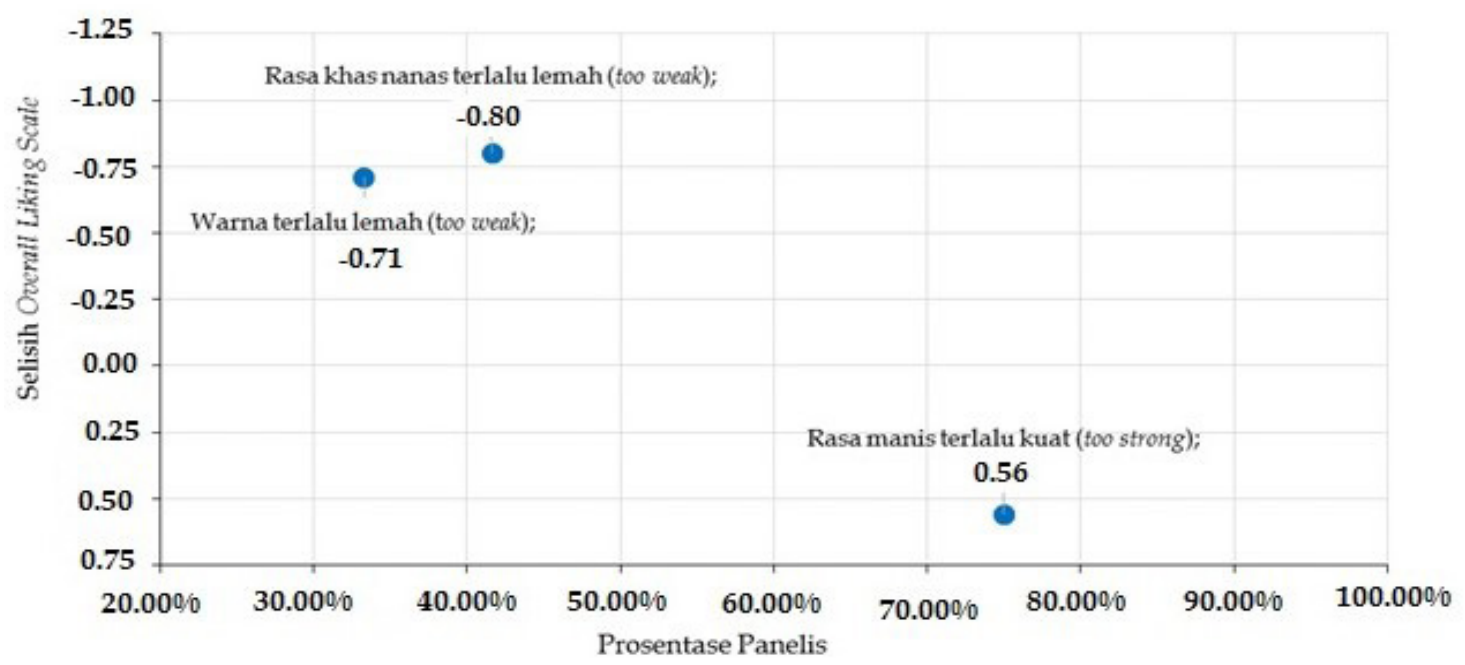

Gambar 9. Analisa penalty (mean drop) minuman buah nanas queen grade C 
dimana $1 \mathrm{~mol}$ asam sitrat (berat molekul $192.12 \mathrm{~g})$ dapat berekasi dengan $3 \mathrm{~mol} \mathrm{OH}-$, oleh karena itu 1 mol NaOH setara dengan $64.04 \mathrm{~g}$ asam sitrat (192.12 : 3).

\section{Analisis Total Padatan Terlarut}

Uji total padatan terlarut (TPT) menggunakan hand refractometer, yaitu dengan meneteskan sampel sirup pada kaca sensor yang ada pada hand refractometer. Selanjutnya dilakukan pembacaan skala dengan melihat pada teropong refractometer. Total padatan terlarut dinyatakan dalam persen Brix ('Brix).

\section{Analisis Viskositas}

Analisis viskositas menggunakan alat elcometer 2300 RV, yaitu dengan cara memasukkan alat sensor ke dalam cairan sampel. Hasil pengukurannya dinyatakan dalam nilai sentipoise $(\mathrm{cP})$.

\section{Analisis Warna}

Analisis warna menggunakan alat colorimeter, yaitu dengan cara menempelkan sampel pada kaca sensor. Hasil pengukuran warna dinyatakan dalam nilai $\mathrm{L}, \mathrm{a}^{*}$ dan $b^{*}$. Nilai L yang menunjukkan light, nilai $a^{*}$ menunjukkan warna merah dan hijau, dan $b^{*}$ menunjukkan warna kuning dan biru.

\section{Analisis Total Mikroba (BPOM, 2008)}

Perhitungan kandungan mikroba dilakukan dengan TPC (total plate count) yang dilakukan pada cawan petri. Minuman buah yang telah diproduksi diambil sampel kemudian dilakukan pengenceran dan diuji kandungan mikroba dengan pour plate pada cawan petri kemudian diinkubasi pada suhu $30{ }^{\circ} \mathrm{C}$ selama $72 \mathrm{jam}$.

\section{Analisis Komparatif Dua Sampel Independen (Siregar, 2015)}

Analisa komparatif kualitas minuman buah nanas menggunakan t-test independent karena data yang digunakan berupa rasio dan terdapat dua sampel independen atau tidak saling berhubungan. Data yang digunakan adalah data tiga ulangan sampel produk.

\section{Uji Organoleptik Minuman Buah Nanas Queen Grade C.}

Uji organoleptik berupa acceptance test menggunakan just-about-right-scale (JARS) yang dikombinasikan dengan overall liking skala 1 sampai dengan 5 (tidak menyukai sampai dengan menyukai). Data yang dihasilkan akan dianalisa menggunakan penalty (mean drop) analysis.

Terdapat 12 responden semi-ahli yang merupakan pelaku usaha atau karyawan perusahaan di bidang industri minuman ringan. Pada penelitian ini, atribut yang diuji meliputi warna, aroma, rasa khas nanas, rasa manis, rasa masam, dan kekentalan.

Mengacu kepada Rothman and Parker (2009), pada analisa penalty (mean-drop), terlebih dahulu dihitung prosentase responden yang menyatakan atribut produk telah tepat (JAR), terlalu lemah (too weak) dan terlalu kuat (too strong). Bilamana lebih dari 20\% responden menyatakan atribut produk terlalu lemah (too weak) atau terlalu kuat (too strong) maka dihitung selisih rata-rata overall liking antara non JAR-JAR. Kesimpulan atau penalty tergantung nilai selisih rerata JAR - non JAR, yaitu:

- Jika >0, maka Positive drop

- Jika 0 - 0.99, maka very slightly concerning

- Jika (-)1.00 - (-)1.49, maka slightly concerning

- Jika (-)1.50 - (-)199, maka concernin

- Jika < (-)2.00, maka very concerning (Rothman and Parker, 2009).

\section{HASIL DAN PEMBAHASAN}

\section{Hasil Analisa Kualitas Minuman Buah}

Hasil analisa kadar gula pada minuman buah nanas Queen grade C dan grade B sebagaimana Gambar 1. Pada penelitian ini, rata-rata kadar air minuman buah nanas Queen yang dihasilkan dari grade C adalah $83.40 \%$, dan yang dihasilkan dari grade B adalah $83.53 \%$. Hasil ini menunjukkan bahwa kandungan yang dominan pada minuman buah adalah air. Hal ini dikarenakan sari buah yang digunakan tergolong tinggi kandungan airnya dan adanya penambahan air minum pada saat proses pengolahan.

Minuman buah termasuk ke dalam kategori minuman ringan tidak berakhohol (BPOM, 2016). Berdasarkan hal ini, maka hasil penelitian sesuai dengan Ashurst (2005), yang menyampaikan bahwa komponen yang paling dominan pada minuman ringan adalah air. Hasil analisa total gula, total asam dan TPT pada minuman buah nanas Queen grade C dan grade B sebagaimana Gambar 2, Gambar 3, dan Gambar 4. 
Nilai total padatan terlarut (TPT) pada sari buah menunjukkan konstituen terlarut yang sebagian besar berupa gula, dan sebagian kecil berupa asam organik, vitamin, protein dan bahan lainnya Hardy dan Sanderson (2010). Hasil penelitian menunjukkan rata-rata karakteristik pada minuman buah nanas Queen grade C yaitu total gula $14.46 \%$; total asam $0.96 \%$; TPT 15.70 'brix. Karakteristik pada minuman buah nanas Queen grade B, yaitu total gula $14.31 \%$; total asam $0.99 \%$; TPT $15.90{ }^{\circ}$ brix. Pada minuman ini, kandungan gula dan asam berasal dari sari buah, dan gula serta asam sitrat yang ditambahkan saat pengolahan.

Sinha et al., (2012) menyajikan karakteristik penting pada sari buah nanas yang masih segar, yaitu nilai TPT 11.2-16.2 g/100 g; total asam $0.46-1.21 \mathrm{~g} / 100 \mathrm{ml}$; fruktosa 1.72-4.75 $\mathrm{g} / 100 \mathrm{ml}$; glukosa 1.21-4.52 g/100 ml; dan sukrosa 2.45-9.73 g/100 (total fruktosa, glukosa, dan sukrosa adalah 5.38-19.00 g/100 ml).

Pada penelitian Nuraeni (2018), nilai rata-rata karakteristik sari buah nanas Queen grade C yaitu total gula $14.98 \%$; total asam 1.01\%; TPT 15.90 'brix. Karakteristik sari buah nanas Queen grade B, yaitu: total gula $13.96 \%$; total asam $1.08 \%$; TPT $15.97{ }^{\circ}$ brix. Berdasarkan hal tersebut, minuman buah nanas Queen grade C dan grade B memiliki nilai rata-rata total gula, total asam, dan TPT yang masih masuk ke dalam rentang nilai sari buah nanas segar, serta relatif mendekati nilai rata-rata sari buah nanas Queen grade $C$ dan grade $B$ tersebut. Hal ini sesuai dengan Ashurst (2005), yang menyampaikan bahwa minuman ringan merupakan minuman kesegaran yang meniru atau mengembangkan rasa sari buah.

Hasil rata-rata warna minuman buah nanas Queen grade C dan grade B pada penelitian ini sebagaimana Gambar 5. Mengacu pada Jha (2010), hasil pengukuran warna menunjukkan beberapa notasi, yaitu nilai L menunjukkan lightness dimana axis $0=$ hitam dan $100=$ putih; nilai a (merah-hijau) dimana axis positif $=$ merah, sedangkan axis negatif $=$ hijau; nilai $b$ (biru-kuning) nilai positif = kuning, sedangkan nilai negatif $=$ biru .

Hasil penelitian menunjukkan bahwa minuman buah nanas Queen grade $\mathrm{C}$ memiliki rata-rata warna, yaitu $\mathrm{L}=22.20 ; \mathrm{a}^{*}=6.20$; $b^{*} 5.93$, sedangkan, yang grade B memiliki warna, yaitu $L=21.73 ; a^{*}=6.13 ; b^{*} 6.30$. Hasil ini menunjukkan bahwa baik minuman buah nanas Queen grade C maupun grade B, sa- ma-sama memiliki nilai $b^{*}$ yang positif yang menunjukkan bahwa produk memiliki unsur warna kuning sebagaimana buah nanas matang. Hal ini sesuai dengan Samadi (2014) dan Cahyono (2012), bahwa daging buah nanas Queen yang telah matang berwarna kuning.

Nilai rata-rata viskositas minuman buah nanas Queen grade C dan grade B ditampilkan pada Gambar 6. Viskositas pada zat cair didefinisikan sebagai resistensi internal untuk mengalir (Ahmed and Rahman, 2012). Gambar 6 menunjukkan bahwa viskositas minuman nanas Queen grade $C$ adalah $3.33 \mathrm{cP}$ dan yang grade B adalah $4.00 \mathrm{cP}$. Data tersebut menunjukkan bahwa viskositas kedua produk adalah rendah. Rendahnya viskositas pada minuman buah nanas Queen grade $\mathrm{C}$ dan grade $\mathrm{B}$ dikarenakan sebagian besar terdiri dari air, yaitu $83.40 \%$ untuk yang dibuat dari grade $C$, dan $83.53 \%$ untuk yang dibuat dari grade B. Hal ini sesuai dengan Arhurst (2005) yang menyampaikan bahwa air memiliki viskositas yang rendah, yaitu $1.00 \mathrm{cP}$ pada suhu $20^{\circ} \mathrm{C}$. Demikian pula Sinha et al. (2012) yang menyatakan bahwa sari buah tergolong memiliki viskositas yang rendah. Hasil rata-rata Total Plate Count (TPC) pada minuman buah nanas Queen grade C dan grade B sebagaimana Gambar 7. Syarat mutu minuman buah belum diatur secara khusus oleh Badan Standarisasi Nasional (BSN). Minuman buah masuk ke dalam kategori sebagai produk minuman berbasis air berperisa tidak berkarbonat (BPOM, 2016). Produk minuman golongan kategori tersebut yang telah diatur mutunya oleh BSN adalah minuman sari buah yang mengandung sari buah $35-89 \%$. Berdasarkan kondisi ini maka TPC minuman buah nanas Queen dibandingkan dengan syarat TPC SNI minuman sari buah yang ditetapkan oleh BSN.

Nilai rata-rata TPC minuman buah nanas Queen grade C adalah $5.33 \times 10^{2}$ koloni/ $\mathrm{ml}$, dan yang grade $\mathrm{B}$ adalah $4.67 \times 10^{2}$ koloni/ ml. BSN (2014) melalui SNI 3719:2014 mengenai minuman sari buah, menetapkan syarat mutu TPC maksimal adalah $1 \times 10^{4}$ koloni/ $\mathrm{ml}$. Berdasarkan ini, maka nilai TPC minuman buah nanas Queen grade C dan grade B memenuhi syarat mutu SNI minuman sari buah.

\section{Hasil Analisa Komparatif Kualitas Minuman Buah}

Pada tahap ini terdapat penghitungan nilai rerata, varian dan t-hitung terhadap has- 
il analisa sifat minuman buah nanas Queen grade $\mathrm{C}$ dan grade $\mathrm{B}$. Hasil analisa $t$-test independent terhadap karakteristik tersebut sebagaimana pada Tabel 1 .

Hasil dari analisa t-test independent menunjukkan bahwa seluruh nilai t-hitung pada rentang nilai (-)4.604 sampai dengan 4.604 sehingga seluruh HO diterima, yang berarti tidak ada perbedaan nilai rata-rata kualitas antara minuman buah nanas Queen grade $\mathrm{C}$ dengan yang dibuat dari grade $\mathrm{B}$.

Pada penelitian ini variasi pada perlakuan percobaan hanya pada bahan baku yang digunakan yaitu nanas Queen grade $C$ dan grade $B$, sehingga grade nanas merupakan faktor yang dapat memberikan pengaruh adanya perbedaan kualitas minuman buah yang dihasilkan. Penelitian Nuraeni (2018), menunjukkan bahwa tidak ada perbedaan antara nilai rata-rata sifat kadar air, total gula, total asam, TPT, warna, viskositas, dan TPC sari buah nanas Queen grade C dengan sari buah nanas Queen grade B.

Direktorat Budidaya Tanaman Buah (2010) menetapkan bahwa setiap grade samasama memiliki kadar gula 11-15 'brix dan warna kulit agak kuning. Salah satu ciri nanas yang matang adalah TPT minimum $12{ }^{\circ}$ brix (Sinha et al., 2012). Demikian pula warna kulit buah menguning juga merupakan tanda kematangan buah (Pathaveerat et al., 2008; Siddiq, 2012; Cahyono, 2012; Li et al., 2018).

Hasil dari penelitian terkait dan berbagai literatur diatas menunjukkan bahwa baik nanas Queen grade C maupun grade B memiliki tingkat kematangan yang sama. Sesuai pula dengan informasi dari pihak penyuluh pertanian wilayah Gunung Kelud-Kabupaten Kediri, yang menyampaikan bahwa nanas Queen grade C dengan grade lainnya merupakan buah yang sama-sama matang, namun grade C memiliki ukuran lebih kecil.

Berdasarkan hal-hal tersebut diatas, maka tidak adanya perbedaan nilai rata-rata kualitas antara minuman buah nanas Queen grade $\mathrm{C}$ dengan yang dibuat dari grade $\mathrm{B}$, dikarenakan tidak adanya perbedaan nilai rata-rata sifat fisikokimia antara sari buah nanas Queen grade C dengan grade C, dan juga kedua grade buah nanas tersebut memiliki tingkat kematangan yang relatif sama.

\section{Perbandingan Kualitas Minuman Buah Nanas Grade C dengan Regulasi}

Penelitian menunjukkan hasil perhitungan bahwa pada komposisi buah:air $=1: 1$ (b:v) dapat menghasilkan air buah yang mengandung sari buah $30.25 \%$ dan air 69.75\%, sehingga komposisi pada saat pencampuran bahan-bahan minuman buah nanas menjadi sebagai berikut, yaitu sari buah $27.50 \%$; air $63.41 \%$; gula $8.93 \%$; asam sitrat $0.09 \%$; CMC $0.04 \%$; dan natrium benzoat $0.02 \%$.

Regulasi yang mengatur definisi minuman buah di Indonesia adalah BPOM. Dan berdasarkan hal maka minuman buah nanas Queen grade C tersebut telah sesuai ke dalam kategori minuman buah BPOM (2016), yaitu minuman yang mengandung total sari buah sebanyak 10-35\%.

\section{Hasil Uji Organoleptik Minuman Buah Nanas Queen Grade C}

Hasil kuisioner dari 12 panelis semiahli direkapitulasi dan dihitung prosentase yang menyatakan tingkat ketepatan atribut produk, dan hasilnya sebagaimana Gambar 8. Terdapat kurang dari $20 \%$ panelis yang menyatakan bahwa atribut aroma, rasa masam, dan kekentalan produk adalah terlalu lemah (too weak) atau terlalu kuat (too strong), sehingga tingkat atribut tersebut dinilai telah tepat dan di-drop yaitu tidak dilakukan analisa selisih overall liking. Terdapat lebih dari $20 \%$ panelis yang menyatakan bahwa tingkat atribut warna dan rasa khas nanas adalah terlalu lemah (too weak), dan rasa manis adalah terlalu kuat (too strong). Hasil perhitungan selisih overall liking dan penalti terhadap atribut tersebut sebagaimana Gambar 9.

Lebih dari $20 \%$ panelis, menyatakan bahwa tingkat warna produk terlalu lemah (too weak). Rata-rata overall liking panelis yang menyatakan atribut terlalu lemah (too weak) adalah 4.00, sedangkan untuk panelis yang menyatakan atribut tersebut telah tepat (JAR) adalah 4.71. Selisih overall liking antara yang menyatakan atribut JAR - too weak adalah (-)0.71 dan menghasilkan penalti very slightly concerning sehingga tidak diperlukan perubahan tingkat atribut. Demikian pula untuk atribut rasa khas nanas, yaitu sebanyak lebih dari $20 \%$ panelis menyatakan tingkat atribut tersebut terlalu lemah (too weak), yang menunjukkan rata-rata overall liking 3.80. Panelis yang menyatakan atribut tersebut telah tepat (JAR) memiliki rata-rata overall liking 4.60. Selisihnya menjadi sebesar (-)0.80 dan menghasilkan penalti very slightly concerning, sehingga tidak diperlukan perubahan tingkat atribut (Mielby et al., 2016; Ramsey et al., 2018; Vad Andersen et al., 2019; Samant dan Seok Seo, 2019) 
Terdapat lebih dari $20 \%$ panelis menyatakan bahwa tingkat rasa manis produk terlalu kuat (too strong), dengan rata-rata overall liking sebesar 4.22. Panelis yang menyatakan atribut tersebut telah tepat (JAR) memiliki overall liking 3.67. Terdapat selisih overall liking sebesar 0.56 dan menghasilkan penalti positive drop. Hal ini menunjukkan bahwa panelis memang menyukai minuman buah yang kuat tingkat kemanisannya. Hasil analisa penalty (mean drop) menunjukkan bahwa selisih rata-rata overall liking non JAR-JAR masih pada kisaran very slightly concerning. Berdasarkan hasil ini, tidak perlukan adanya perubahan komposisi minuman buah nanas yang dapat mempengaruhi perubahan seluruh tingkat atribut produk.

\section{SIMPULAN}

Berdasarkan hasil penelitian ini dapat disimpulkan bahwa tidak ada perbedaan nilai rata-rata kualitas minuman buah antara yang dihasilkan dari nanas Queen grade $\mathrm{C}$ dengan grade $\mathrm{B}$. Hasil penelitian terkait dan beberapa literatur menunjukkan bahwa kondisi ini dikarenakan tidak adanya perbedaan nilai rata-rata sifat fisikokimia antara sari buah nanas Queen grade $C$ dengan grade C, dan juga kedua grade buah nanas tersebut memiliki tingkat kematangan yang relatif sama. Kandungan sari buah pada minuman buah nanas Queen grade C sebesar 27.50\% sehingga telah sesuai dengan regulasi kategori pangan BPOM yang mengatur bahwa kandungan sari buah pada minuman buah adalah antara $10-35 \%$. Hasil analisa penalty (mean drop) menunjukkan bahwa atribut aroma, rasa khas nanas, dan kekentalan adalah drop dan tidak memerlukan analisa selisih rata-rata overall liking on JAR-JAR. Hasil analisa selisih rata-rata overall liking Non JARJAR untuk atribut rasa manis adalah positive drop, sedangkan untuk atribut warna dan rasa khas nanas adalah very slightly concerning. Berdasarkan hal tersebut maka dapat disimpulkan bahwa atribut sensori pada minuman buah nanas Queen grade C telah tepat dan tidak memerlukan perubahan komposisi.

\section{DAFTAR PUSTAKA}

Ahmed, J, Rahman, MS. 2012. Handbook of Food Process Design. John Wiley \& Sons, USA

Amador, JR. 2011. Laboratory Manual Procedures for Analysis of Citrus Products. John Bean Technologies Corporation Inc, Florida.

Apriyantono, A, Fardiaz, D, Puspitasari, NL, Sedarnawati, Budiyanto, S. 1989. Petunjuk Laboratorium Analisis Pangan. PAU Pangan dan Gizi. IPB, Bogor

Ashurst, PR. 2005. Chemistry and Technology of Soft Drinks and Fruit Juices. Blackwell Publishing Ltd, Oxford

Badan Pengawas Obat dan Makanan (BPOM). 2016. Peraturan kepala badan pengawas obat dan makanan republik indonesia nomor 21 Tahun 2016 tentang kategori pangan. Dilihat 10 Januari 2019. <http:/ / standarpangan.pom. go.id/dokumen/peraturan/2016/ PerKa_BPOM_No_21_Tahun_2016_ tentang_Kategori_Pangan.pdf $>$

Badan Pengawas Obat dan Makanan (BPOM). 2008. Kriteria mikrobiologi dalam pangan olahan. Dilihat 10 Agustus 2016. <http://standarpangan.pom.go.id/ dokumen/peraturan/2016/PerKa_ BPOM_No_16_Tahun_2016_tentang Kriteria_Mikrobiologi_dalam_Pangan_Olahan.pdf>

Badan Pusat Statistik (BPS). 2016. Produksi buah-buahan (mangga, nanas, pepaya, pisang dan rambutan) menurut kabupaten/kota di provinsi jawa barat. Dilihat 8 November $2016 . \quad<$ https://jabar.bps.go.id/ statictable/2018/03/14/325/produksi-buah-buahan-manggananas-pepaya-pisang-dan-rambutanmenurut-kabupaten-kota-di-provinsijawa-barat-2016.html>

Badan Pusat Statistik Kabupaten Blitar. 2016. Kabupaten blitar dalam angka 2016. Dilihat 08 Desember 2016. <https://blitarkab.bps.go.id/publication/2016/07 /15/9479afd1c780418d334088d0/kabupaten-blitar-dalam-angka-2016.html>

Badan Pusat Statistik Kabupaten Kediri. 2016. Kabupaten kediri dalam angka 2016. Dilihat 07 Desember 2016. <https:// kedirikab.bps.go.id/publication/2016/07/15/ 9c25371b1bfd944022f82c2a/kabupatenkediri-dalam-angka-2016.html> 
Cahyono, B. 2012. Buku Terlengkap Budidaya Nenas Secara Komersial. Pustaka Mina, Jakarta

Direktorat Budidaya Tanaman Buah. 2010. Standar prosedur operasional (SPO) nenas jawa timur. Dilihat 25 Mei 2016. <http:/ / Ditbuah.hortikultura.pertanian.go.id >

Featherstone, S. 2016. A Complete Course in Canning and Related Processes. Woodhead Publishing., UK

Food and Agriculture Organization of The United Nations. 2013. Data production crops pineapple. Dilihat 10 Mei 2016. <http://www.fao.org/land-water/ databases-and-software/crop-information/pineapple/en/>

Hardy, S, Sanderson, G. 2010. Citrus maturity testing. Dilihat 09 November 2018. <https://www.dpi.nsw.gov.au/_. data/assets/pdf_file/0020/320294/ Citrus-maturity-testing.pdf $>$

Jha, SH. 2010. Nondestructive Evaluation of Food Quality Theory and Practice. Springer

Khairani, C, Dalapati, A. 2007. Petunjuk teknis pengolahan buah-buahan, balai pengkajian teknologi pertanian (BPTP) sulawesi tengah. Dilihat 10 Januari 2018. <http:/ / sulsel.litbang.pertanian. go.id/ind/images/lakip-2013.pdf>

Lawless, HT, Heymann, H. 2010. Sensory Evaluation of Food Principles and Practices. Springer, New York

Lia, -X., Zhua, -X., Wang, -H., Lin, -X., Lin, -H., Chen, -W., 2018. Postharvest application of wax controls pineapple fruit ripening and improves fruit quality. Postharvest Biology and Technology. 136, Pages 99-110. https://doi. org/10.1016/j.postharvbio.2017.10.012

Mielby, L, -H., Andersen, B, -V., Jensen, -S., Kildegaard, -H., Kuznetsova, -A., Eggers, -N., Brockhoff, P, -B., Byrne, D, -V., 2016. Changes in sensory characteristics and their relation with consumers' liking, wanting and sensory satisfaction: Using dietary fibre and lime flavour in Stevia rebaudiana sweetened fruit beverages. Food Research International. 82, 14-21. https://doi. org/10.1016/j.foodres.2016.01.010

Nuraeni, Y. 2018. Perancangan Agroindustri Berbasis Nanas Queen grade C (Ananas comosus (L) Merr.) Menjadi Konsentrat Sari Buah dan Minuman Buah. Tesis. Universitas Brawijaya, Malang
Pathaveerat, -S., Terdwongworakul, -A., Phaungsombut, -A., 2008. Multivariate data analysis for classification of pineapple maturity. Journal of Food Engineering. 89, 112-118. https://doi. org/10.1016/j.jfoodeng.2008.04.012

Ramsey, -I., Ross, -C., Ford, -R., Fisk, -I., Yang, -Q., Gomez-Lopez, -J., Hort, -J., 2018. Using a combined temporal approach to evaluate the influence of ethanol concentration on liking and sensory attributes of lager beer. Food Quality and Preference. 68, 292303. https://doi.org/10.1016/j.foodqual.2018.03.019

Rothman, L, Parker, MJ. 2009. Just-AboutRight (JAR) Scales: Design, Usage, Benefits and Risks. ASTM International, West Conshohocken

Samadi, B. 2014. Panen Untung dari Budi Daya Nanas Sistem Organik. Andi Yogyakarta, Yogyakarta

Samant, S, -S., Seok Seo, -H., 2019. Using both emotional responses and sensory attribute intensities to predict consumer liking and preference toward vegetable juice products. Food Quality and Preference. 73, 75-85. https://doi.org/10.1016/j.foodqual.2018.12.006

Siddiq, M. 2012. Tropical and Subtropical Fruits Postharvest Physiology Processing and Packaging. John Wiley \& Sons Inc, USA

Sinha, N, Sidhu, J, Barta, J, Wu, J, Cano, MP. 2012. Handbook of Fruits and Fruit Processing. John Wiley \& Sons Ltd, USA

Siregar, S. 2015. Statistik Parametrik Untuk Penelitian Kuantitatif. Bumi Aksara, Jakarta

Sudarmadji, S, Haryono, B, Suhardi. 2010. Prosedur Analisa Untuk Bahan Makanan dan Pertanian. Liberty Yogyakarta, Yogyakarta

Tiara, T, D, S. 2014. Pembuatan Permen Jelly dari Buah Nanas (Ananas comosus L) Subgrade (Kajian Konsentrasi Karagenan dan Gelatin). Skripsi. Universitas Brawijaya, Malang

Vad Andersen, -B., Brockhoff, P, -B., Hyldig, -G., 2019. The importance of liking of appearance, -odour, -taste and -texture in the evaluation of overall liking. A comparison with the evaluation of sensory satisfaction. Food Quality and Preference. 71, 228-232. https://doi. org/10.1016/j.foodqual.2018.07.005 
Jurnal Teknologi Pertanian Vol. 20 No. 1 [April 2019] 67-78

Analisis Kualitas dan Uji Organoleptik Minuman Buah [Nuraeni dkk]

Yusmarini, Emrinaldi, Johan, V, -S., 2015.

Karakterisasi mutu kimiawi mikrobiologi dan sensori sari buah campuran nanas dan semangka. Jurnal Teknologi dan Industri Pertanian Indonesia. 7, 1823. http://doi.org/10.17969/jtipi. v7i1.2829 